\title{
Simultaneous Determination of Metformin and Pioglitazone in Presence of Metformin Impurity by Different Spectrophotometric and TLC - Densitometric Methods
}

\author{
Amal Khorshid ${ }^{1}$, Nessreen S Abdelhamid ${ }^{2}$, Eglal A Abdelaleem ${ }^{2}$ and Mahmoud M Amin ${ }^{1}$ \\ ${ }^{1}$ L1Analytical Chemistry Department, Faculty of Pharmacy, Nahda University, Egypt \\ ${ }^{2}$ Analytical Chemistry Department, Faculty of Pharmacy, Beni_Suef University, Egypt
}

Received: May 21, 2018; Accepted: June 21, 2018; Published: June 22, 2018

*Corresponding author: Amal Khorshid, Associate professor, Department of Pharmaceutical Analytical Chemistry, Facultly of Pharmacy, Nahda University, Egypt, E-mail: amalkorshid@yahoo.com or amal.khorshed@nub.edu.eg

\begin{abstract}
New simple accurate methods were developed and validated for simultaneous determination of Metformin hydrochloride and Pioglitazone hydrochloride in presence of Metformin impurity Melamine, both in bulk powder and in pharmaceutical preparation using spectrophotometric methods and thin layer chromatography - Method A used zero order spectrophotometric technique for determination of Pioglitazone at $268 \mathrm{~nm}$ and isoabsorbtive point spectrophotometric technique to determine Metformine at $255 \mathrm{~nm}$ in presence of the other drugs and used double divisor technique to determine Metformine in presence of the other drugs at $254 \mathrm{~nm}$. Method $\mathrm{B}$ uses TLC densitometric technique for separation and simultaneous determination of the three drugs using toluene / methanol / acetic acid (5:5:0.5) as a developing system and $240 \mathrm{~nm}$ as a scanning wavelength.
\end{abstract}

This method were validated and shown to demonstrate good accuracy and precision according to ICH guidelines.

Keywords: Metformin hydrochloride; Pioglitazone hydrochloride; Melamine; Double Divisor and TLC Densitometry;

\section{Introduction}

Metformin $\mathrm{HCl}$ (MET) is N; N dimethyl imido dicarbonimidic diamide hydrochloride .It is an antidiabitic drug from the biguanide class used in the management of type 2 diabetes. The major action of Metformin is increasing glucose transport across the cell membrane in skeletal muscles [1].

Pioglitazone $\mathrm{HCl}$ (PIO) is $( \pm)-5$-[p-[2-(5-ethyl-2-pyridyl)ethoxy] benzyl]-2, 4-thiazolidinedione hydrochloride [2]. It is an anti-diabetic drug from the thiazolidinedione hydrochloride class of drugs [3] MET and PIO combination is impartment for patients suffering from type 2 diabetes who require treatment with more than one anti-hyperglycemic drug to achieve optimal glycemic control [2].

Melamine (MEL) is 1, 3, 5-Triazine-2, 4, 6-triamine; and it is a potential impurity of Metformin. A variety of toxic effects from Melamine, including nephrolithiasis, chronic kidney inflammation and bladder carcinoma.

The literature review show that MET was determined in its bulk powder by liquid chromatography (LC) [4-10] and spectroscopy [11, 12] and capillary electrophoresis [13-15], Pioglitazone was determined by liquid chromatography (LC) [16-19], and capillary electrophoresis [20]. The binary mixture of MET and PIO was determined by some spectrophotometric methods [21-23] and determined by reversed phase liquid chromatography [2, 24-26].

The aim of this work is to develop and validate new analytical methods able to determine the tertiary mixture Metformin, Pioglitazone and Melamine in bulk powder and pharmaceutical dosage form without interference or prior separation.

\section{Experimental}

\section{Instruments}

Double beam UV_Visible spectrophotometer (SHIMADZU, Japan) .model uv-1601 PC with quartz cell of $1 \mathrm{~cm}$ path length connected to IBM compatible computer. The software is uv - pc personal spectroscopy version 3.7.

TLC scanner densitometer (Camag, Muttenz, Switzerland). The following requirements were taken into consideration: slit dimensions, $5 \times 0.2 \mathrm{~mm}$; scanning speed, $20 \mathrm{~mm} / \mathrm{s}$; spraying rate, $10 / \mathrm{mL}$; data resolution: $100 \mathrm{~mm} / \mathrm{step}$. Pre-coated silica gel aluminum plates $(20 \times 10 \mathrm{~cm} ; 60 \mathrm{~F} 254)$ were obtained from Fluka, Sigma-Aldrich Chemie Gmbh, and Germany. The sample applicator for TLC was a Linomat IV with a $100 \mathrm{~mL}$ syringe (Camag, Muttenz, Switzerland).

\section{Pure standards}

Standard MET and PIO with claimed purity of 99.88\%and 99.98\% respectively according to manufacturer certificate were kindly supplied by Sigma Pharmaceuticals Industries (El Monofeya, Egypt).

Melamine was purchased from sigma Aldrich chemie (Germany) with certified purity of $99.7 \%$.

\section{Pharmaceutical dosage forms}

Bioglita plus tablets batch no. [15675] were manufactured 
by Amoun pharmaceutical Co.SAE (Cairo _ Egypt). Labeled to contain $850 \mathrm{mg}$ of Metformin $\mathrm{HCl}$ and $15 \mathrm{mg}$ of Pioglitazone $\mathrm{HCl}$.

\section{Solvents and reagents}

All reagents and chemicals used were of analytical grade and were used without further purification; they included:

(i) Methanol analar (Central Drug House Ltd., India)

(ii) Toluene and glacial acetic acid (Al-Nasr Pharmaceutical chemicals company, Abu Zaabal cairo - Egypt).

\section{Prepared solutions}

\section{Standard stock solutions $(1 \mathrm{mg} / \mathrm{ml})$}

An amount of $0.025 \mathrm{gm}$ of each drug were accurately weighed into 3 separated $25 \mathrm{ml}$ volumetric flask , then the volume in each flask was made up to the mark with methanol

\section{Standard working solution $(100 \mu \mathrm{g} / \mathrm{ml})$}

A volume of $2.5 \mathrm{ml}$ of each stock solution of drugs were diluted to $25 \mathrm{ml}$ with methanol in 3 separated $25 \mathrm{ml}$ volumetric flasks.

\section{Laboratory prepared mixtures}

Mixtures containing different ratios of MET, PIO and MEL were prepared using their standard working solutions in methanol.

\section{Methodology}

\section{Linearity and construction of calibration curve}

\section{Spectrophotometric method}

Different aliquots of PIO, MET and MEL were transferred from working solution $(100 \mu \mathrm{g} / \mathrm{ml})$ to three separate series of $10 \mathrm{ml}$ volumetric flask and the volume was completed to the mark by methanol to obtained concentration ranges $(3 \mu \mathrm{g} / \mathrm{ml}-25 \mu \mathrm{g} /$ $\mathrm{ml}),(10 \mu \mathrm{g} / \mathrm{ml}-50 \mu \mathrm{g} / \mathrm{ml})$ and ( $10 \mu \mathrm{g} / \mathrm{ml}-33 \mu \mathrm{g} / \mathrm{ml})$ from PIO , MET and MEL respectively . The spectrum of each concentration was recorded against methanol as blank. The spectra were observed for selecting of the suitable wavelength for zero order, double divisor and isoabsorptive point.

\section{HPTLC - densitometric method}

Into 3 different groups of $10 \mathrm{ml}$ volumetric flasks aliquots of MET, PIO and MEL were accurately transferred from their working solution, the volume was then made up with methanol. A $10 \mu \mathrm{l}$ aliquots of each solution was spotted as band of $5 \mathrm{~mm}$ width on TLC plates to obtain concentration ranges of ( $3-20 \mu \mathrm{g}$ ), (3 -
$12 \mu \mathrm{g}$ ) and ( 0.5 - 5 $\mu \mathrm{g}$ ) PIO , MET and MEL respectively .

The peak area were recorded using a scanning wavelength of $240 \mathrm{~nm}$ and calibration curves were constructed by plotting the integrated peak area versus the concentration in $\mu \mathrm{g} /$ band for each compound and the regression equations were computed.

\section{Analysis of laboratory prepared mixtures}

Accurate aliquots were transferred from MET, PIO and MEL working solutions into a series of $10 \mathrm{ml}$ volumetric flasks completed to volume with methanol and mixed well to obtain tertiary mixtures of different ratios then the absorption spectra of each solution was recorded and the same procedures mentioned under calibration curves were applied in order to determine MET , PIO and MEL in the laboratory prepared mixtures by both spectrophotometric techniques and TLC densitometric method.

\section{Application to pharmaceutical formulation}

Bioglita plus tablet are labeled to contain $850 \mathrm{mg}$ MET and $15 \mathrm{mg}$ PIO per tablet. The contents of 10 tablets were powdered. An amount of the powder equivalent to $100 \mathrm{mg}$ of MET and PIO were separately transferred into $100 \mathrm{ml}$ volumetric flask, $50 \mathrm{ml}$ of methanol was added to each of them and sonicated for $30 \mathrm{~min}$ , cooled and then the volume was completed to mark to obtained $1000 \mu \mathrm{g} / \mathrm{ml}$ of MET and PIO stock solution and then the solution was filtered. Appropriate dilution of the prepared solutions were made to prepare working solutions containing $100 \mu \mathrm{g} / \mathrm{ml}$ of each of PIO and MET and the procedures under construction of calibration curves were followed for both spectrophotometric techniques and TLC densitometric method.

\section{Result and discussion}

\section{Spectrophotometric methods}

Spectrophotometry is a widely used analytical technique because of its simplicity, low cost and its time consuming

\section{Determination of PIO by zero order}

PIO can be determined by zero order spectrophotometry at $268 \mathrm{~nm}$ where MET and MEL show no absorbance (Figure 2).

The absorbance spectra of pure PIO solutions of different concentrations (3_25 $\mu \mathrm{g} / \mathrm{ml}$ ) are recorded against methanol as blank (Figure 3).

The calibration curve was constructed relating the absorbance of PIO at $268 \mathrm{~nm}$ to concentration $(\mu \mathrm{g} / \mathrm{ml}$ ) and the regression equation was computed showing a linear relationship (Figure 4).
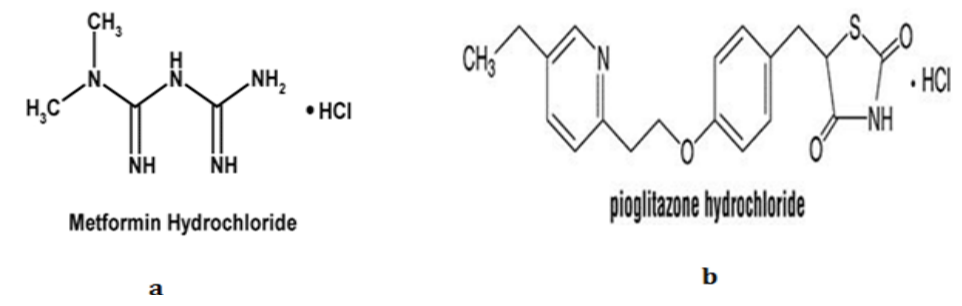

b<smiles>Nc1nc(N)nc(N)n1</smiles>

c

Figure1: Chemical structure of (a) Metformin hydrochloride, [b] Pioglitazone hydrochloride and (c) Melamine 


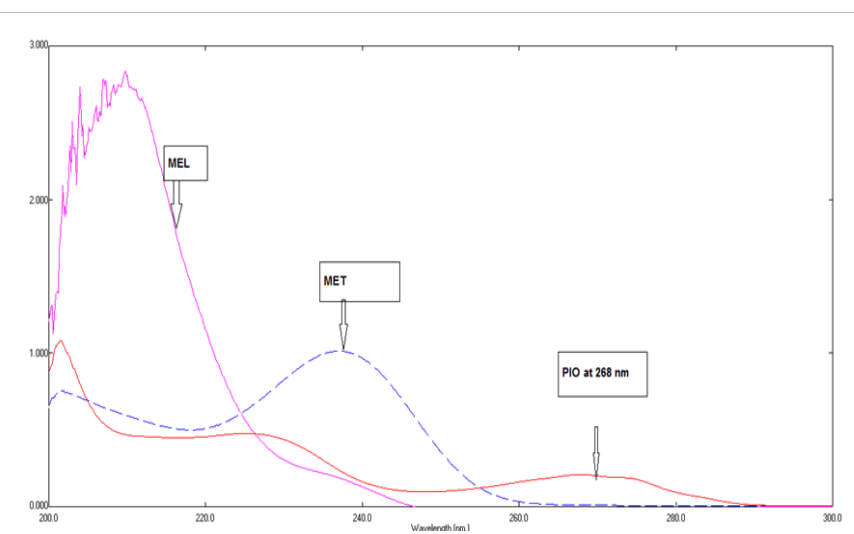

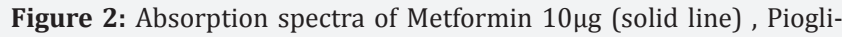
tazone $10 \mu \mathrm{g}$ (dashed line ) and Melamine (dotted line ) $10 \mu \mathrm{g}$

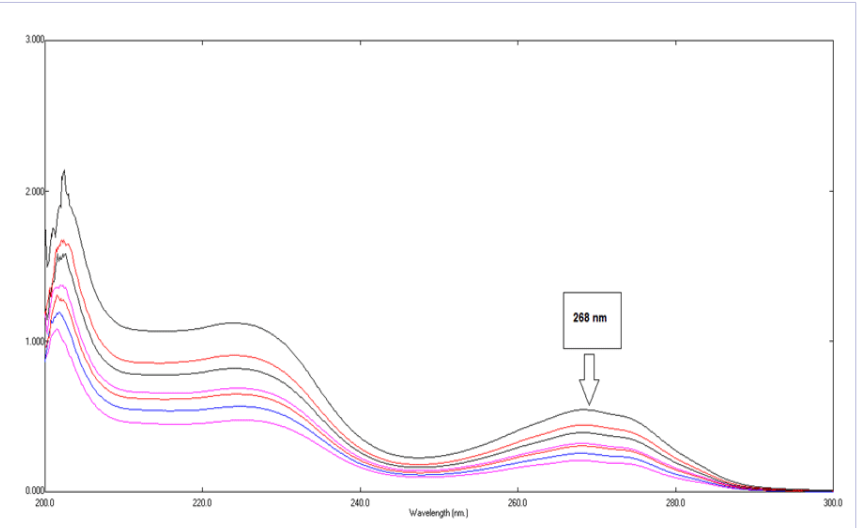

Figure 3: The UV absorbance spectra of different concentration (3 - 25 $\mu \mathrm{g} / \mathrm{ml}$ ) of PIO

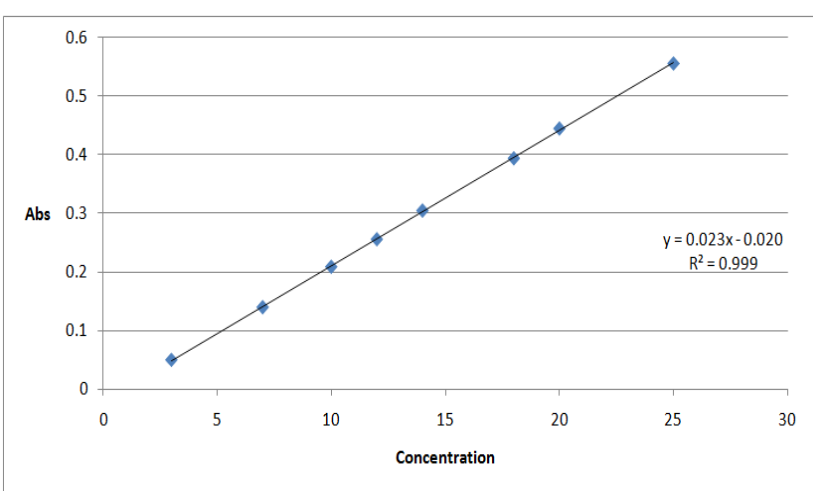

Figure 4: Calibration curves relating the absorbance of PIO at $268 \mathrm{~nm}$ to the concentration $(\mu \mathrm{g} / \mathrm{ml})$

\section{Double divisor method ratio spectra for determination of Metformin 254nm}

Absorption spectra of pure MET, different ternary mixture and dosage form solutions were recorded and divided by the standard spectrum of PIO / MEL binary mixture containing $10 \mu \mathrm{g} / \mathrm{ml}$ of each and the second derivative of the spectra was obtained ( using 4 as delta lamda and 10 as scaling factor ) (Figure 5 ).
A calibration curve relating the peak amplitude of MET at $254 \mathrm{~nm}$ to the concentration in $\mu \mathrm{g} / \mathrm{ml}$ was constructed and the regression equation was computed showing good linearity in the concentration range of $(10-45 \mu \mathrm{g} / \mathrm{ml})$ (Figure 6 and 7)

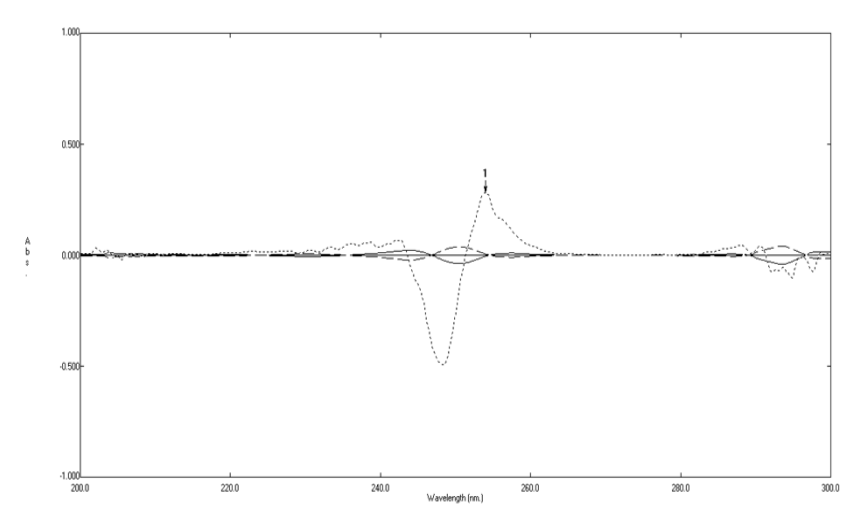

Figure 5: The double divisor second derivative spectra of MET , MEL and PIO using (PIO and MEL $10 \mu \mathrm{g}$ ) as divisor

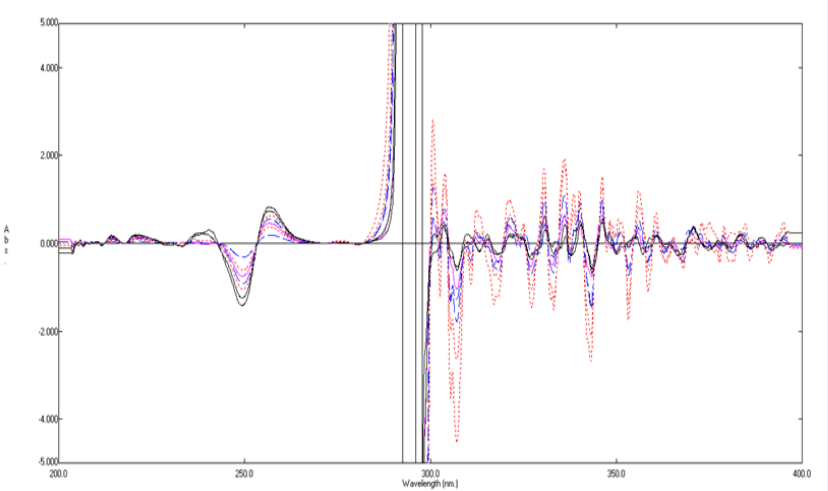

Figure 6: Double divisor second derivative spectra of pure MET (10 $45 \mu \mathrm{g} / \mathrm{ml})$ using PIO /MEL $(10 \mu \mathrm{g} / \mathrm{ml})$ as divisor

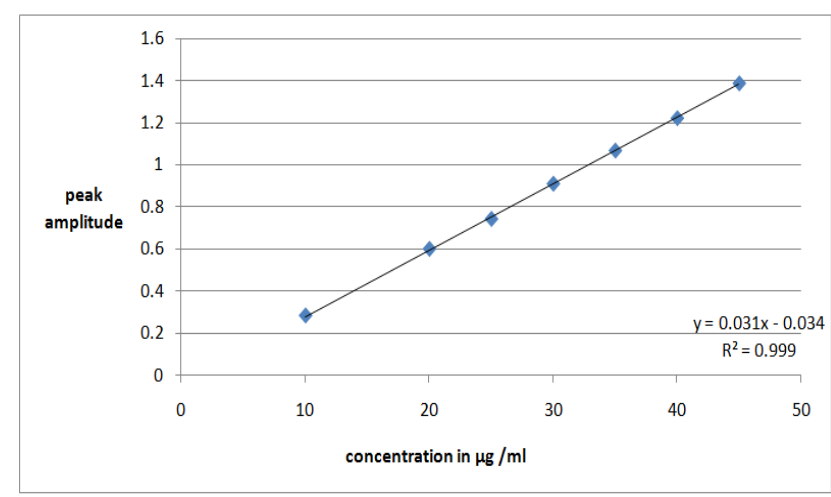

Figure 7: Calibration curve relating peak amplitude of double divisor second derivative spectra of 4 MET to its concentration in $\mu \mathrm{g} / \mathrm{ml}$. 
Isoabsorptive point spectrophotometric method for determination of MET in presence of PIO and MEL

\section{Determination of Metformin at $255 \mathrm{~nm}$ ( isoabsorptive point ) using methanol as blank}

In the isoabsorptive point technique, the concentration of PIO was determined by measuring the absorbance at $268 \mathrm{~nm}$. Then calculate the total mixture concentration by measuring the absorbance at $255 \mathrm{~nm}$. To determine the absorbance of MET we subtract absorbance of the calculated concentration of PIO from the total absorbance of mixture at $255 \mathrm{~nm}$. A calibration curve was constructed relating the absorbance of PIO at 268 $\mathrm{nm}$ to concentration $(\mu \mathrm{g} / \mathrm{ml}$ ) and the regression equation was computed showing a linear relationship (Figure 9).

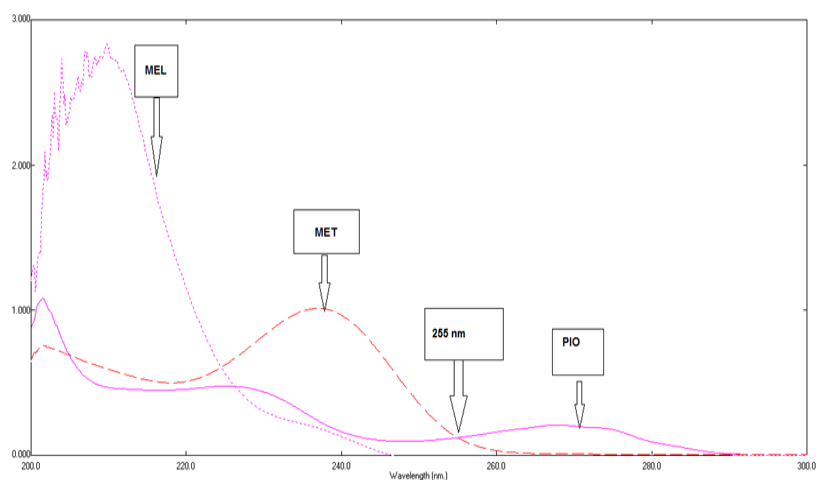

Figure 8: MET $10 \mu \mathrm{g}$ (dash line ) , PIO $10 \mu \mathrm{g}$ ( solid line) and MEL 10 $\mu \mathrm{g}$ ( dot line )

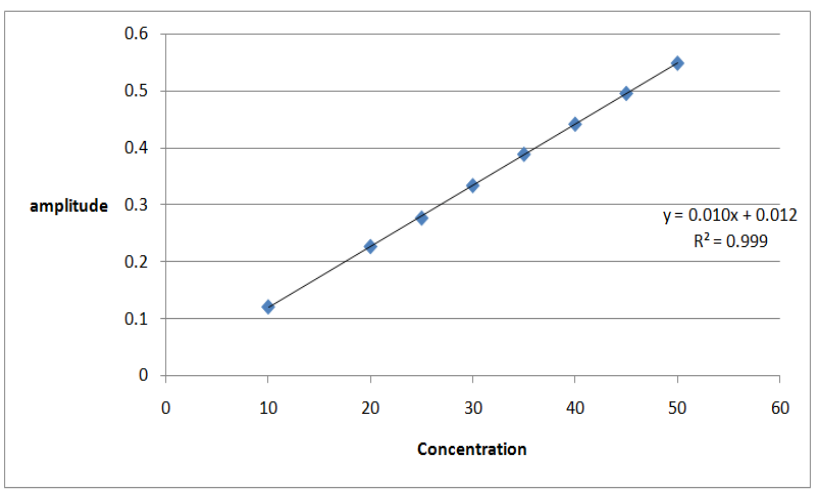

Figure 9: Calibration curve relating the peak amplitude of MET at 255 $\mathrm{nm}$ to the concentration

\section{Tlc - densitometric method}

The TLC densitometric technique was successfully applied for the determination of MET, PIO and MEL in pure form, mixtures and dosage form. This method offers a simple way to quantify directly on TLC plate by measuring the optical density of the separated bands, in order to obtain optimum separation among the studied drugs. Different trials have been carried out to reach the optimum developing system ,scanning wavelength, band dimension and slit dimension [27].
Different developing systems with different ratios have been tested such as toluene: methanol, chloroform: methanol and toluene: methanol: acetic acid

The best results concerning chromatographic separation, peak symmetry and linearity were obtained upon using the system (toluene - methanol - acetic $(5: 5: 0.5)$ by volume). The obtained Rf values were $0.8,0.2$ and 0.5 for PIO, MET and MEL, respectively (Figure 10 and 11 ).

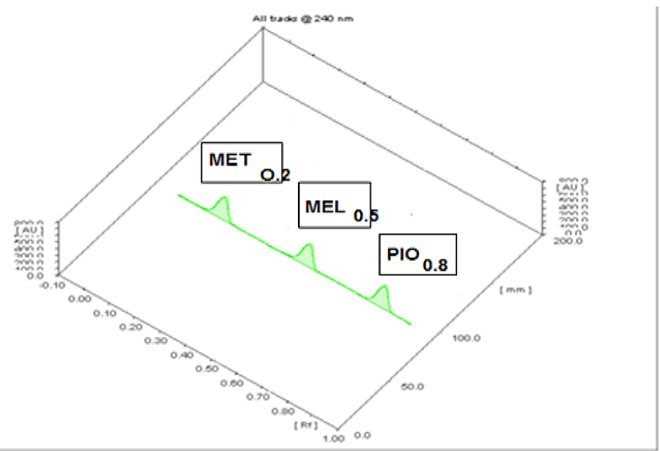

Figure 10: TLC densitogram of mixture of MET , PIO and MEL.

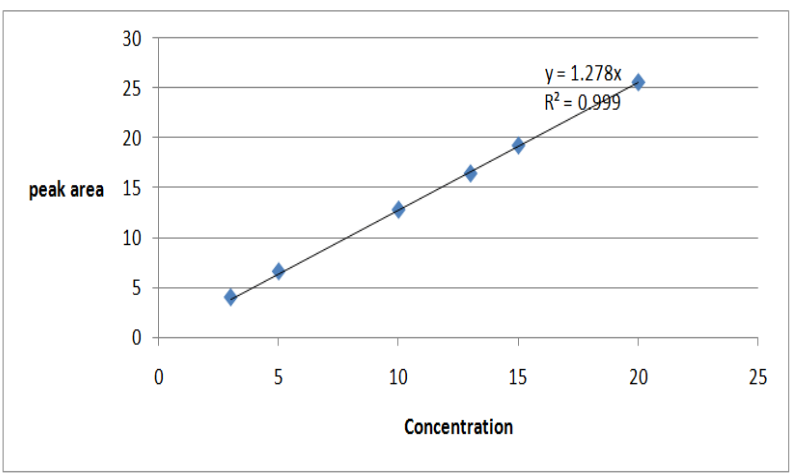

Figure 11: Calibration curve relating the peak area of TLC peaks of PIO to its concentration in $\mu \mathrm{g} / \mathrm{band}$.

Different scanning wavelength such as $210 \mathrm{~nm} .225 \mathrm{~nm}$ and $240 \mathrm{~nm}$ were tried but $240 \mathrm{~nm}$ was the best scanning wavelength that showed high sensitivity with minimum noise for all the drugs.

Calibration curves were plotted to related the integrated peak area versus the corresponding concentrations in the

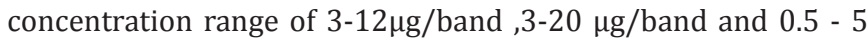
$\mu \mathrm{g} /$ band for MET ,PIO and MEL respectively (Figure 11, 12 and 13 ) . The regression equations were computed and found to be:

$\begin{array}{ll}\text { AMEL }=3.6831 \mathrm{C}+0.0117 & \mathrm{R}^{2}=0.9999 \\ \text { AMET }=2.78 \mathrm{C}-0.8607 & \mathrm{R}^{2}=0.9996 \\ \text { APIO }=1.2787 \mathrm{C} & \mathrm{R}^{2}=0.9997\end{array}$




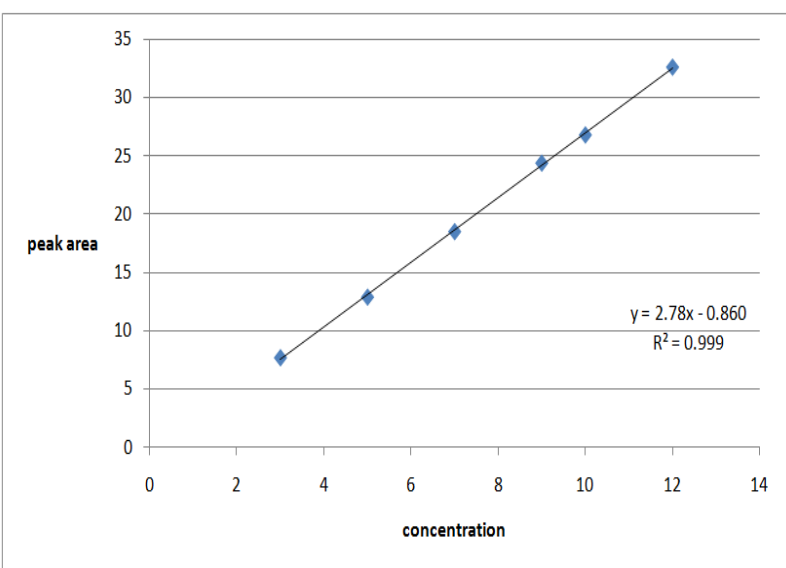

Figure 12: Calibration curve relating the peak area of TLC peaks of MET to its concentration in $\mu \mathrm{g} / \mathrm{band}$.

\section{Method validation}

\section{Validation of the methods was carried out according to ICH recommendation}

\section{Linearity and range}

The calibration range of the studied drugs was established through considerations of the practical range necessary according to Beer-lamberts law to give accurate, precise and linear results. Linearity ranges are shown in table [1].

Good linearity is evident from the high values of the correlation coefficient and low values of intercept

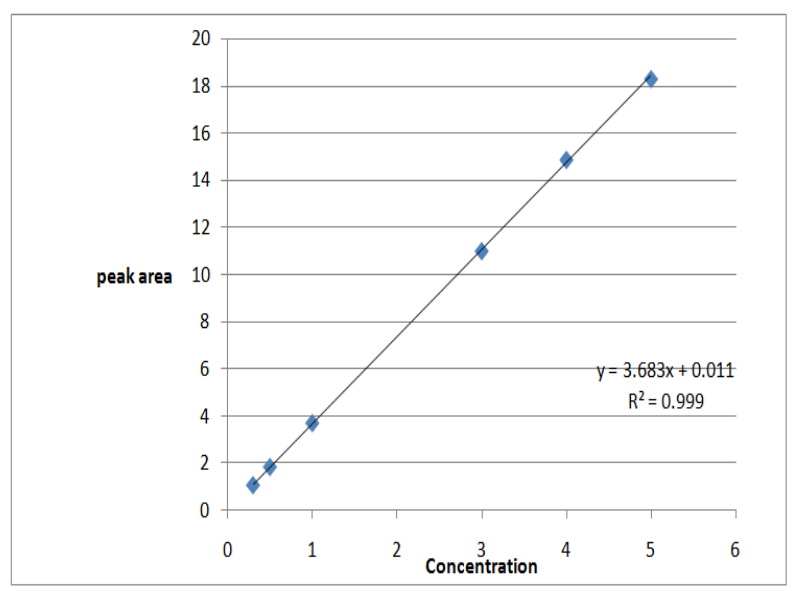

Figure 13: Calibration curve relating the peak area of TLC peaks of MEL to its concentration in $\mu \mathrm{g} / \mathrm{band}$.

\section{Accuracy}

Accuracy of the proposed methods was calculated as the percentage recoveries of pure samples of the studied drugs. The concentrations were calculated from the corresponding regression equations and the results are shown in (Table 1).

\section{Precision}

\section{Repeatability}

Three concentrations $(5,10,15 \mu \mathrm{g} \mathrm{mL}-1$ of MET and PIO) were analyzed three times intra-daily using the proposed methods. Good results and acceptable relative standard deviations (RSDs) were obtained (Table 1).

Table 1: Regression and analytical parameters of the proposed zero order, isospestic point, double divisor and TLC -densitometric methods for determination of Metformin, Pioglitazone and Melamine

\begin{tabular}{|c|c|c|c|c|c|c|}
\hline \multirow[t]{2}{*}{ Parameters } & \multirow{2}{*}{$\begin{array}{c}\text { Zero order } \\
\text { PIO }\end{array}$} & \multirow{2}{*}{$\begin{array}{c}\text { Double divisor } \\
\text { MET }\end{array}$} & \multirow{2}{*}{$\begin{array}{c}\text { Isospestic point } \\
\text { MET }\end{array}$} & \multicolumn{3}{|c|}{ TLC-densitometric method } \\
\hline & & & & PIO & MET & MEL \\
\hline Range & $3-25 \mu \mathrm{g}$ & $10-45 \mu \mathrm{g}$ & $10-50 \mu \mathrm{g}$ & $3-20 \mu \mathrm{g}$ & $3-12 \mu \mathrm{g}$ & $0.5-5 \mu \mathrm{g}$ \\
\hline Slope & 0.0231 & 0.03153 & 0.0107 & 1.2 & 2.7 & 3.68 \\
\hline Intercept & 0.0207 & -0.0341 & 0.0119 & 0.07 & 0.8 & 0.019 \\
\hline Correlation coefficient & 0.9999 & 0.999903 & 0.9999 & 0.9997 & 0.9996 & 0.9999 \\
\hline $\begin{array}{c}\text { Precision } \\
\text { Repeatability } \\
\text { RSD }\end{array}$ & 0.689 & 0.72 & 0.756 & 1.08 & 1.1 & 1.45 \\
\hline Intermediate ${ }^{\mathrm{B}}$ precision RSD & 0.731 & 0.75 & 0.876 & 1.17 & 1.3 & 1.65 \\
\hline
\end{tabular}




\section{Intermediate precision}

The previous procedure was repeated interdaily on 3 different days for the analysis of the chosen concentration. Good results and acceptable RSD s were obtained.

\section{Selectivity}

Selectivity of the proposed analytical method was assessed by the analysis of different synthetic laboratory mixtures contained different ratio of (MET and PIO) within their linearity ranges satisfactory results are shown in table 2 .

Specificity of the proposed methods are evident from the spectrophotometric mehods and HPTLC in figure 11which also show no interference between them.

\section{Robustness}

The recommended TLC-Densitometric method was found to remain unchanged with small changes in method parameters e.g.: changing acetic acid ratio in the developing system \pm 0.02 $\mathrm{mL}$, changing saturation time $\pm 5 \mathrm{~min}$ and changing the scanning wavelength $\pm 1 \mathrm{~nm}$. Which assessed the robustness of the validated method

\section{System suitability testing parameters}

When system suitability testing was done, we obtained acceptable results and the peaks information was given in the resolution (Rs) and selectivity factors $(\alpha)$ values were above 1 and 1.5, respectively, which ensured good separation of each component from the other (Table 4).

Table 2: Determination of Metformin, Pioglitazone and Melamine in laboratory prepared mixtures by the spectrophotometric method

\begin{tabular}{|c|c|c|c|c|c|c|}
\hline Drugs & \multicolumn{2}{|c|}{ pioglitazone } & \multicolumn{2}{c|}{ Metformin } \\
\hline Method & \multicolumn{2}{|c|}{ Zero order } & \multicolumn{2}{c|}{ double divisor } & \multicolumn{2}{|c|}{ Isospestic point } \\
\hline Mix .no. & Taken & Recovery & Taken & Recovery & Taken & Recovery \\
\hline 1 & 20 & 101.8 & 25 & 102.1079 & 20 & 99.14 \\
\hline 2 & 15 & 100.3 & 30 & 101.8095 & 25 & 100.1 \\
\hline 3 & 10 & 99.8 & 50 & 101.2127 & 30 & 99.8 \\
\hline 4 & 12 & 101.6 & 40 & 98.7381 & 40 & 90.13 \\
\hline 5 & 18 & 101.4 & 45 & 99.05467 & 45 & 99.8 \\
\hline 6 & 14 & 101.94 & 20 & 98.5873 & 50 & 99.6 \\
\hline Mean \pm RSD & \multicolumn{2}{|c|}{$101.4 \pm 0.83$} & $100.2517 \pm 1.63034$ & & $99.9 \pm 0.5$ \\
\hline
\end{tabular}

\begin{tabular}{|c|c|c|c|c|c|c|c|c|c|c|c|c|}
\hline \multirow{2}{*}{$\begin{array}{c}\text { Pharmaceutical } \\
\text { preparation }\end{array}$} & \multirow[t]{2}{*}{ TLC } & & & \multicolumn{9}{|c|}{ SPECTROPHOTOMETRIC METHODS } \\
\hline & & \multicolumn{3}{|c|}{ ZERO ORDER } & \multicolumn{3}{|c|}{ ISOSPESTIC } & \multicolumn{3}{|c|}{ DOUBLE DIVISOR } & \multirow[b]{2}{*}{$\begin{array}{l}\text { FOUND } \\
(\% \pm \mathrm{SD})\end{array}$} & \multirow[b]{2}{*}{$\begin{array}{l}\text { STANDARD } \\
\text { ADDITION } \\
\text { TECNIQUE } \\
\text { (mean } \pm \text { SD) }\end{array}$} \\
\hline Bioglita plus & $\begin{array}{c}\text { Taken } \\
(\mu \mathrm{g} / \\
\text { band) }\end{array}$ & $\begin{array}{l}\text { Found } \\
(\% \pm S D)\end{array}$ & $\begin{array}{c}\text { Standard } \\
\text { addition } \\
\text { technique } \\
\text { (mean } \pm \text { SD) }\end{array}$ & $\begin{array}{l}\text { TAKEN } \\
(\mu \mathrm{g} / \mathrm{ml})\end{array}$ & $\begin{array}{l}\text { FOUND } \\
(\% \pm S D)\end{array}$ & $\begin{array}{l}\text { STANDARD } \\
\text { ADDITION } \\
\text { TECNIQUE } \\
\text { (mean } \pm \text { SD) }\end{array}$ & $\begin{array}{l}\text { TAKEN } \\
(\mu \mathrm{g} / \mathrm{ml})\end{array}$ & $\begin{array}{l}\text { FOUND } \\
(\% \pm S D)\end{array}$ & $\begin{array}{l}\text { STANDARD } \\
\text { ADDITION } \\
\text { TECNIQUE } \\
\text { (mean+ SD) }\end{array}$ & $\begin{array}{l}\text { TAKEN } \\
(\mu \mathrm{g} / \mathrm{ml})\end{array}$ & & \\
\hline Met & 5 & $100.2 \pm 0.54$ & $100.14 \pm 1.09$ & & & & 30 & $90.4 \pm .49$ & $98.7 \pm .4$ & 15 & $95.89 \pm 1.6$ & $102.45 \pm 1.4$ \\
\hline Pio & 7 & $99.8 \pm 0.34$ & $101.3 \pm 1.19$ & 10 & $99.8 \pm 0.86$ & $100.9 \pm 0.73$ & & & & & & \\
\hline
\end{tabular}

Table 4: System suitability testing parameters of TLC densitometric method

\begin{tabular}{|c|c|c|c|}
\hline Parameters & PIO & MET & MEL \\
\hline Selectivity factors & 1.44 & & 2.09 \\
\hline Resolution & 3.4 & 4 & 2.4 \\
\hline Capacity factors & 0.25 & 0.59 & 1 \\
\hline Symmetry factors & 0.8 & & 0.77 \\
\hline
\end{tabular}


Table 5: It shows the statistical comparison of the results obtained by the proposed methods and the established method

\begin{tabular}{|c|c|c|c|c|c|c|c|}
\hline \multirow[t]{2}{*}{ Items } & \multicolumn{3}{|c|}{ HPTLC } & \multicolumn{2}{|c|}{$\begin{array}{l}\text { Spectrophotometric } \\
\text { methods }\end{array}$} & \multicolumn{2}{|c|}{ Reported HPLC method $^{\mathrm{c}}$ [26] } \\
\hline & MET & PIO & MEL & MET & PIO & MET & PIO \\
\hline Mean & 100.1 & 101.3 & 99.8 & 100.46 & 99.98 & 101.1667 & 100.7167 \\
\hline SD & 1.2 & 2.2 & 1.2 & 0.75 & 0.68 & 1.47196 & 1.738294 \\
\hline $\mathbf{N}$ & 6 & 6 & 6 & 6 & 6 & 6 & 6 \\
\hline Student T test ${ }^{\text {a }}$ & 0.5 & 0.3 & 0.6 & 2.6 & 0.01 & & \\
\hline F - value ${ }^{b}$ & 0.3 & 0.9 & 0.16 & 0.2 & 0.7 & & \\
\hline
\end{tabular}

${ }^{\text {a }}$ figures in parentheses represent the corresponding tabulated values of $\mathrm{T}$ at $\mathrm{P}=0.05$

${ }^{\mathrm{B}}$ figures in parentheses represent the corresponding tabulated values of $\mathrm{F}$ at $\mathrm{P}=0.05$

${ }^{\mathrm{C}}$ HPLC method : on a Hypersil ODS-C18 column with $5 \mu \mathrm{m}$ particle size using the mobile phase acetonitrile-water-acetic acid (75 $+25+0.3$ ), adjusted to $\mathrm{pH} 5.5$ with liquor ammonia, at a flow rate of $0.5 \mathrm{~mL} / \mathrm{min}$ [26]

\section{Conclusion}

The developed methods have advantages over the published methods in being more simple, rapid, cost effective and data processing steps are not time consuming. Spectrophotometric methods can be regarded as a useful alternative to chromatographic techniques in the routine quality control analysis of pharmaceutical formulations allowing rapid determination at relatively low cost. The advantages of TLC-densitometric method is its ability to determine the studied drugs using one and the same developing system and scanning wavelength, several samples can be run simultaneously using a small quantity of mobile phase unlike HPLC, thus lowering analysis time and cost . The developed methods can be easily adopted for routine quality control analysis of MET and PIO.

The advantages of this spectrophotometric methods are reducing time and cost. Also the proposed TLC -densitometric method has the advantage of being more sensitive than other developed method.

\section{References}

1. Patil Sudarshan S and C Bonde. Development and Validation of analytical method for Simultaneous Estimation of Glibenclamide and Metformin $\mathrm{HCl}$ in Bulk and Tablets using UV-visible spectroscopy. International Journal of ChemTech Research. 2009;1(4):905-909.

2. Lakshmi K, T Rajesh and S Sharma. Simultaneous determination of metformin and pioglitazone by reversed phase HPLC in pharmaceutical dosage forms. International Journal of Pharmacy and Pharmaceutical Sciences. 2009;1(2):162-166.

3. Hegazy MA, El-Ghobashy MR, Yehia AM, Mostafa AA. Simultaneous determination of metformin hydrochloride and pioglitazone hydrochloride in binary mixture and in their ternary mixture with pioglitazone acid degradate using spectrophotometric and chemometric methods. Drug Test Anal. 2009;1(7):339-349. doi: 10.1002/dta.60

4. Zarghi A, Foroutan SM, Shafaati A, Khoddam A. Rapid determination of metformin in human plasma using ion-pair HPLC. J Pharm Biomed Anal. 2003;31(1):197-200.
5. Valentina P, Grigoleto SP, Eunice KK, Eunice EK, Yara PA, KazuoF, et al. HPLC-UV determination of metformin in human plasma for application in pharmacokinetics and bioequivalence studies. Journal of pharmaceutical and biomedical analysis. 2008;46(1):143-147.

6. Tache F, Victor David, Alexandru Farca, Andrei Medvedovici. HPLC-DAD determination of Metformin in human plasma using derivatization with p-nitrobenzoyl chloride in a biphasic system. Microchemical journal. 2001;68(1):13-19.

7. Yuen KH and KK Peh. Simple high-performance liquid chromatographic method for the determination of metformin in human plasma. Journal of Chromatography B: Biomedical Sciences and Applications. 1998;710(1):243-246.

8. Cheng $\mathrm{CL}$ and $\mathrm{CH}$ Chou. Determination of metformin in human plasma by high-performance liquid chromatography with spectrophotometric detection. J Chromatogr B Biomed Sci Appl. 2001;762(1):51-58.

9. Huupponen R, Ojala-Karlsson. Determination of metformin in plasma by high-performance liquid chromatography. Journal of Chromatography B: Biomedical Sciences and Applications. 1992;583(2):270-273.

10. Ross M. Determination of metformin in biological fluids by derivatization followed by high-performance liquid chromatography. J Chromatogr. 1977;133(2):408-411

11. Hassan SS, Wagiha H Mahmoud, Mohamed AF, Abdel Hammeed M. Determination of metformin in pharmaceutical preparations using potentiometry. spectrofluorimetry and UV-visible spectrophotometry. Analy tica chimica acta. 1999;378(1-3):299-311.

12. Habib I and M Kamel. Near infra-red reflectance spectroscopic determination of metformin in tablets. Talanta. 2003;60(1):185-190. doi: 10.1016/S0039-9140(03)00123-1

13.Song JZ, Chen HF, Tian SJ, Sun ZP. Determination of metformin in plasma by capillary electrophoresis using field-amplified sample stacking technique. J Chromatogr B Biomed Sci Appl. 1998;708(12):277-283.

14. Hamdan II, Jaber AK, Abushoffa AM. Development and validation of a stability indicating capillary electrophoresis method for the de- 
termination of metformin hydrochloride in tablets. J Pharm Biomed Anal. 2010;53(5):1254-1257. doi: 10.1016/j.jpba.2010.03.017

15.Tůma P. Large volume sample stacking for rapid and sensitive determination of antidiabetic drug metformin in human urine and serum by capillary electrophoresis with contactless conductivity detection. J Chromatogr A. 2014;1345:207-211. doi: 10.1016/j.chroma.2014.04.016

16. Radhakrishna T, DS Rao and GO Reddy. Determination of pioglitazone hydrochloride in bulk and pharmaceutical formulations by HPLC and MEKC methods. J Pharm Biomed Anal. 2002;29(4):593607.

17. Sripalakit P, Neamhom P, Saraphanchotiwitthaya A. High-performance liquid chromatographic method for the determination of pioglitazone in human plasma using ultraviolet detection and its application to a pharmacokinetic study. J Chromatogr B Analyt Technol Biomed Life Sci. 2006;843(2):164-169.

18. Yamashita K, Murakami H, Okuda T, Motohashi M. High-performance liquid chromatographic determination of pioglitazone and its metabolites in human serum and urine. J Chromatogr B Biomed Appl. 1996;677(1):141-146.

19. Lin ZJ, Ji W, Desai Krieger D, Shum L. Simultaneous determination of pioglitazone and its two active metabolites in human plasma by LC-MS/MS. J Pharm Biomed Anal. 2003;33(1):101-108.

20. Calixto LA, PS Bonato. Combination of hollow-fiber liquid-phase microextraction and capillary electrophoresis for pioglitazone and its main metabolites determination in rat liver microsomal fraction. Electrophoresis. 2013 ;34(6):862-869. doi: 10.1002/ elps.201200430
21. Shankar MB, Modi VD, Shah DA, Bhatt KK, Mehta RS, Geetha M, Patel BJ. Estimation of pioglitazone hydrochloride and metformin hydrochloride in tablets by derivative spectrophotometry and liquid chromatographic methods. J AOAC Int. 2005;88(4):1167-1172.

22.Chaturvedi P, R Sharma. Simultaneous spectrophotometric estimation and validation of three component tablet formulation containing pioglitazone hydrochloride, metformin hydrochloride and glibenclamide. Analytical letters. 2008;41(12):2133-2142.

23. Adhikari L, S Jagadev, S Sahoo, PN Murthy, US Mishra. Devlopement and validation of UV-visible spectrophotometric method for simultaneous determination of Pioglitazone Hydrochloride, Metformin Hydrochloride and glipizide in its bulk and pharmaceutical dosage form (tablet). International Journal of ChemTech Research. 2012;4(2):625-630.

24.Jain D, Jain S, Jain D, Amin M. Simultaneous estimation of metformin hydrochloride, pioglitazone hydrochloride, and glimepiride by RPHPLC in tablet formulation. J Chromatogr Sci. 2008;46(6):501-504.

25.El-Ghobashy M, A Yehia, A Mostafa. Application of membrane-selective electrodes for the determination of pioglitazone hydrochloride in the presence of its acid degradant or metformin hydrochloride in tablets and plasma. Analytical Letters. 2009;42(1):123-140.

26. Sahoo PK, Sharma R, Chaturvedi SC. Simultaneous estimation of metformin hydrochloride and pioglitazone hydrochloride by RPHPLC method from combined tablet dosage form. Indian J Pharm Sci. 2008;70(3):383-386. doi: 10.4103/0250-474X.43010

27. Naguib IA, Abdelaleem EA, Zaazaa HE, Draz ME. Simultaneous Determination of Hydrochlorothiazide and Benazepril Hydrochloride or Amiloride Hydrochloride in Presence of Hydrochlorothiazide Impurities: Chlorothiazide and Salamide by HPTLC Method. J Chromatogr Sci. 2015;53(1):183-188. doi: 10.1093/chromsci/bmu016 